University of Nebraska - Lincoln

DigitalCommons@University of Nebraska - Lincoln

USDA National Wildlife Research Center - Staff Publications
U.S. Department of Agriculture: Animal and Plant Health Inspection Service

2013

\title{
Influence of vegetation structure on the small mammal community in a shortgrass prairie ecosystem
}

Craig M. Thompson

Utah State University, cthompson@fs.fed.us

Eric M. Gese

USDA/APHIS/WS National Wildlife Research Center, eric.gese@usu.edu

Follow this and additional works at: https://digitalcommons.unl.edu/icwdm_usdanwrc

Thompson, Craig M. and Gese, Eric M., "Influence of vegetation structure on the small mammal community in a shortgrass prairie ecosystem" (2013). USDA National Wildlife Research Center - Staff Publications. 1198.

https://digitalcommons.unl.edu/icwdm_usdanwrc/1198

This Article is brought to you for free and open access by the U.S. Department of Agriculture: Animal and Plant Health Inspection Service at DigitalCommons@University of Nebraska - Lincoln. It has been accepted for inclusion in USDA National Wildlife Research Center - Staff Publications by an authorized administrator of DigitalCommons@University of Nebraska - Lincoln. 


\title{
Influence of vegetation structure on the small mammal community in a shortgrass prairie ecosystem
}

\author{
Craig M. Thompson • Eric M. Gese
}

Received: 20 March 2012 / Accepted: 2 September 2012 / Published online: 19 September 2012

(C) Mammal Research Institute, Polish Academy of Sciences, Białowieża, Poland (outside the USA) 2012

\begin{abstract}
The structure of vegetation, and how this structure varies across a landscape, is crucial to understanding the distribution of wildlife species. Between 2002 and 2004, we sampled small mammal communities and measured vegetation structure at 185 locations across a range of disturbance regimes in a shortgrass prairie ecosystem in southeastern Colorado, USA. At each sampling location, the local disturbance regime was some combination of varying intensity of livestock grazing, military training activity, and fire. Vegetation structural characteristics measured included percent bare ground, basal cover, litter, shrub density, and mean grass and shrub height. Rodent communities were described by richness, diversity, total and per capita biomass, and species abundances. Northern grasshopper mice (Onychomys leucogaster), Ord's kangaroo rats (Dipodomys ordii), silky pocket mice (Perognathus flavus), western harvest mice (Reithrodontomys megalotis), white-footed mice (Peromyscus leucopus), southern plains wood rats (Neotoma micropus), thirteen-lined ground squirrels (Spermophilus tridecemlineatus), deer
\end{abstract}

Communicated by: Karol Zub

C. M. Thompson

Department of Wildland Resources, Utah State University,

Logan, UT 84322-5210, USA

E. M. Gese $(\square)$

U.S. Department of Agriculture, Wildlife Services,

National Wildlife Research Center,

Department of Wildland Resources, Utah State University,

Logan, UT 84322-5295, USA

e-mail: eric.gese@usu.edu

Present Address:

C. M. Thompson

U.S. Department of Agriculture/Forest Service,

Pacific Southwest Research Station,

Fresno, CA 93710, USA mice (Peromyscus maniculatus), and spotted ground squirrels (Spermophilus spilosoma) accounted for $>99 \%$ of all captures. Canonical correlation analysis was used to assess the relationship between small mammals and vegetation structure. The first two canonical variates explained over $50 \%$ of the variation in vegetation structure and were related to the ratio of bare ground to basal coverage and litter accumulation. Rodent community indices were most strongly related to litter accumulation and shrub density, though the models had low explanatory power. Our results agreed with published findings regarding microhabitat associations and indicated small mammal communities benefited from a system of interacting disturbances and the resulting landscape mosaic.

Keywords Rodents $\cdot$ Vegetation structure $\cdot$ Shortgrass prairie $\cdot$ Diversity $\cdot$ Richness $\cdot$ Small mammals ·

Disturbance $\cdot$ Abundance $\cdot$ Shrub density

\section{Introduction}

Historically, southwestern grassland conditions in the USA were maintained through frequent fires, as well as drought and grazing by native herbivores (Bock and Bock 1990; Knight 1994; Davidson et al. 2010). Along the Great Plains shrubsteppe of the USA, grazing by free-roaming herbivores left significant grass biomass which acted as fuel for frequent lightning-initiated fires. These fires burned with enough frequency and intensity to keep both shrubs and trees from becoming established. Today, fire suppression and intensive livestock grazing have severely altered the natural systems, resulting in a dramatic loss of native grassland (Valone and Kelt 1999). Livestock grazing promotes the conversion of grassland to shrubland through the reduction of vegetation biomass and fuel, as well as the selective removal of nutrient-rich grasses (Berlow et al. 2002; Briggs et al. 2002). The resulting decrease in fire frequency and 
intensity promotes the expansion of unpalatable shrubs such as four-winged saltbrush (Atriplex canescens) and tree cholla (Opuntia imbricata). These changes can cascade through systems resulting in shifts in community composition, richness, and diversity for both herbivores and their predators (Sieg 1997; Lyon et al. 2000). Small mammal communities may be particularly sensitive to these changes due to their energetic demands and the balance between foraging efficiency and security (White et al. 2004; Reed et al. 2005).

For years, wildlife ecologists have known that the structure of vegetation, and how this structure varies across a landscape, is crucial to understanding wildlife distributions (Wiens 1989; Otis 1997). However, an understanding of the exact relationship has been elusive (Turner et al. 2001). This is complicated by the fact that local disturbance regimes vary widely in their components, and these components may be additive, exclusive, or compensatory (Hobbs and Huenneke 1992). For example, in our study area, mechanized infantry training represents a powerful and landscapealtering disturbance. The effects of training may partially mimic those of migratory grazing by herds of native bison (Bison bison), i.e., a massive but rare physical disturbance resulting in vegetation mortality and soil compaction (Milchunas et al. 1999). However, while native ungulates remove biomass through grazing, mechanized infantry training promotes litter accumulation (Milchunas et al. 2000). Add to this the effects of domestic livestock, fire suppression, and the resulting changes in nutrient cycling and the interactions become extremely complex (Knight 1994; Davidson et al. 2010).

From 2002 through 2004, we evaluated the effect of military training activity on wildlife at multiple trophic levels in southeastern Colorado (Thompson and Gese 2007). As part of this research, we sampled rodent communities and measured vegetation structure across a range of management and disturbance regimes. In this paper, we examine the relationship between grassland vegetation structure and small mammals, both at the species and community level, and relate this variation to differences in the local disturbance regime.

\section{Methods}

Study area

We conducted research on and around the $1,040 \mathrm{~km}^{2}$ Piñon Canyon Maneuver Site (PCMS) located in northern Las Animas County, Colorado (Fig. 1). North of the PCMS, in Otero County, the study area extended into the United States Forest Service (USFS), Comanche National Grassland. The study area also extended southward onto private ranchlands. The region was classified as semiarid grassland steppe, with approximately $60 \%$ of the PCMS categorized as shortgrass prairie dominated by blue grama (Bouteloua gracilis), western wheatgrass (Agropyron smithii), and galleta (Hilaria jamesii) (Shaw et al. 1989). Shrublands interspersed throughout the study area included four-winged saltbrush (A. canescens) and greasewood (Sarcobatus vermiculatus), as well as prickly pear cactus (Opuntia phaeacantha), tree cholla (O. imbricata), and yucca (Yucca glauca). The remaining landscape was dominated by pinyon-juniper woodland (Pinus edulis and Juniperus monosperma). Elevation varied between 1,310 and $1,740 \mathrm{~m}$, average temperatures ranged from $1{ }^{\circ} \mathrm{C}$ in January to $23{ }^{\circ} \mathrm{C}$ in July, and annual precipitation averaged $30 \mathrm{~cm}$ but can fluctuate widely (Shaw and Diersing 1990). Monthly precipitation was highest in July with an average of $4.3 \mathrm{~cm}$ of rain, though the $35 \%$ of the annual precipitation that falls during the cool season (March-May) has a proportionally greater impact on productivity (Milchunas et al. 1999).

Throughout the region, a variety of land use practices over two decades has resulted in a wide range of landscape conditions (Fig. 2). South of the PCMS, intensive private ranching maintained sparse basal cover with dense but infrequent stands of tree cholla. North of the PCMS, drought conditions prompted the U.S. Forest Service to halve stocking rates between 1999 and 2002, resulting in moderate basal cover and more frequent tree cholla stands. On the PCMS, mechanized infantry training combined with fire suppression efforts has resulted in a variety of landscape conditions, ranging from heavily disturbed areas of bare ground to dense grassland or shrubland.

\section{Study design}

In 2002, we identified six study sites in areas subjected to three land use regimes: livestock grazing, mechanized military training, and unused. Within each site, we randomly placed $50 \times 70 \mathrm{~m}$ sampling grids at the rate of four grids/site/ season over 3 years. We defined seasons as winter: 15 December-14 April, summer: 15 April-14 August, and fall: 15 August-14 December. New random locations were selected each season, resulting in 12 grids sampled/site/ year (Fig. 1). On each grid, we used line transect surveys (Dale 1999, p. 41) at $10 \mathrm{~m}$ spacing to characterize vegetation structure, resulting in eight $50-\mathrm{m}$ line transects/grid. Parameters measured included percent live basal (vegetative) cover, percent bare ground, percent litter, vegetation height (total, grass, and shrub), and shrub density (number of shrubs $/ 100 \mathrm{~m}^{2}$ ).

Following vegetation sampling, we placed 35 Sherman live traps with $10 \mathrm{~m}$ spacing throughout the grid. Traps were baited with equine sweet feed: a mix of corn, oats, and molasses. Trapping grids were run for four nights; checked and closed each morning and reset each afternoon. Captured 
Fig. 1 Distribution of sampling grids on and around the Piñon Canyon Maneuver Site, southeastern Colorado, USA, 2001-2004

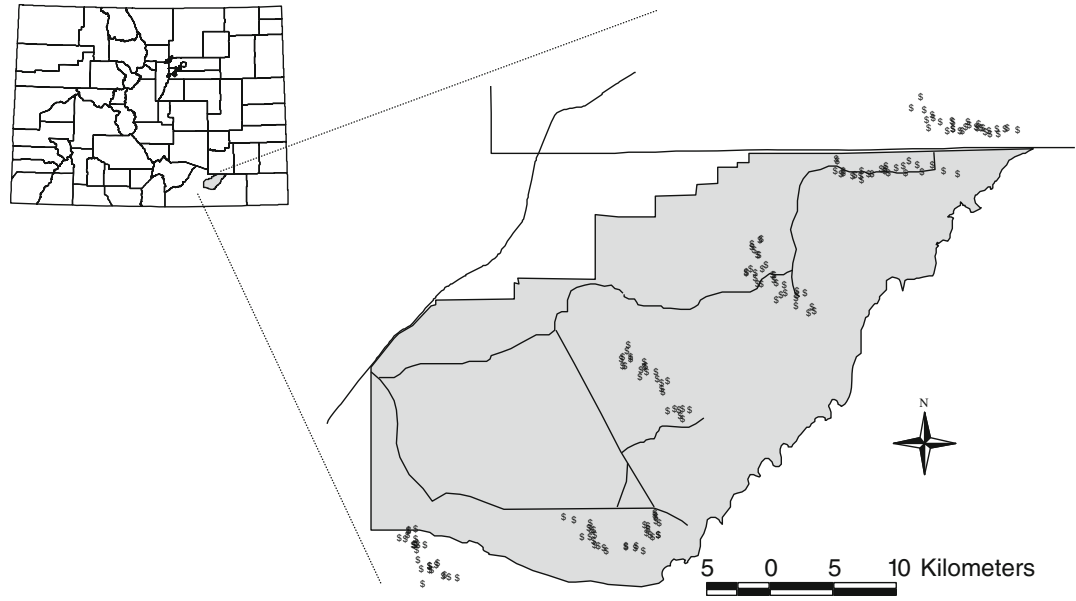

rodents were marked with a permanent ink marker on the tail and abdomen allowing for identification of recaptures over the 4-day trapping period. We calculated species abundance as the number of each species captured per operable trap night, community richness as the number of species captures, and community diversity using the ShannonWeaver index (Morin 1999, p. 18). We estimated biomass, both individual and community, using the species average weight.

\section{Data analysis}

We used canonical correlation analysis (McGarigal et al. 2000 , p. 199) to evaluate the primary gradients in vegetation structure and to assess relationships between the small mammal abundance estimates and structural vegetative characteristics. Vegetation variables were standardized to a mean of 0 and standard deviation of
1 to facilitate direct gradient comparisons (Ter Braak 1986). Where necessary, vegetation variables were log transformed to improve univariate normality and we used Pearson correlation coefficients to identify highly correlated variables. Species abundance estimates were square-root transformed to downplay the statistical influence of grids with high capture rates (Ter Braak 1986). We assessed multivariate normality based on the univariate normality of the canonical variates (McGarigal et al. 2000, p. 199). An ordination diagram based on the first two canonical axes was constructed (Jongman et al. 1995, p. 147).

We evaluated the relationship between structural vegetative characteristics and small mammal community indices (diversity, richness, total biomass, and per capita biomass) using stepwise regression (SAS version 8). Correlations between vegetation variables were evaluated with Pearson correlation coefficients and highly correlated variables were
Fig. 2 Examples of the landscape variability within the study area in southeastern Colorado, USA. Clockwise from the upper left: private ranchlands, USFS Comanche National Grassland, nontraining area on the PCMS, and mechanized infantry training area on the PCMS

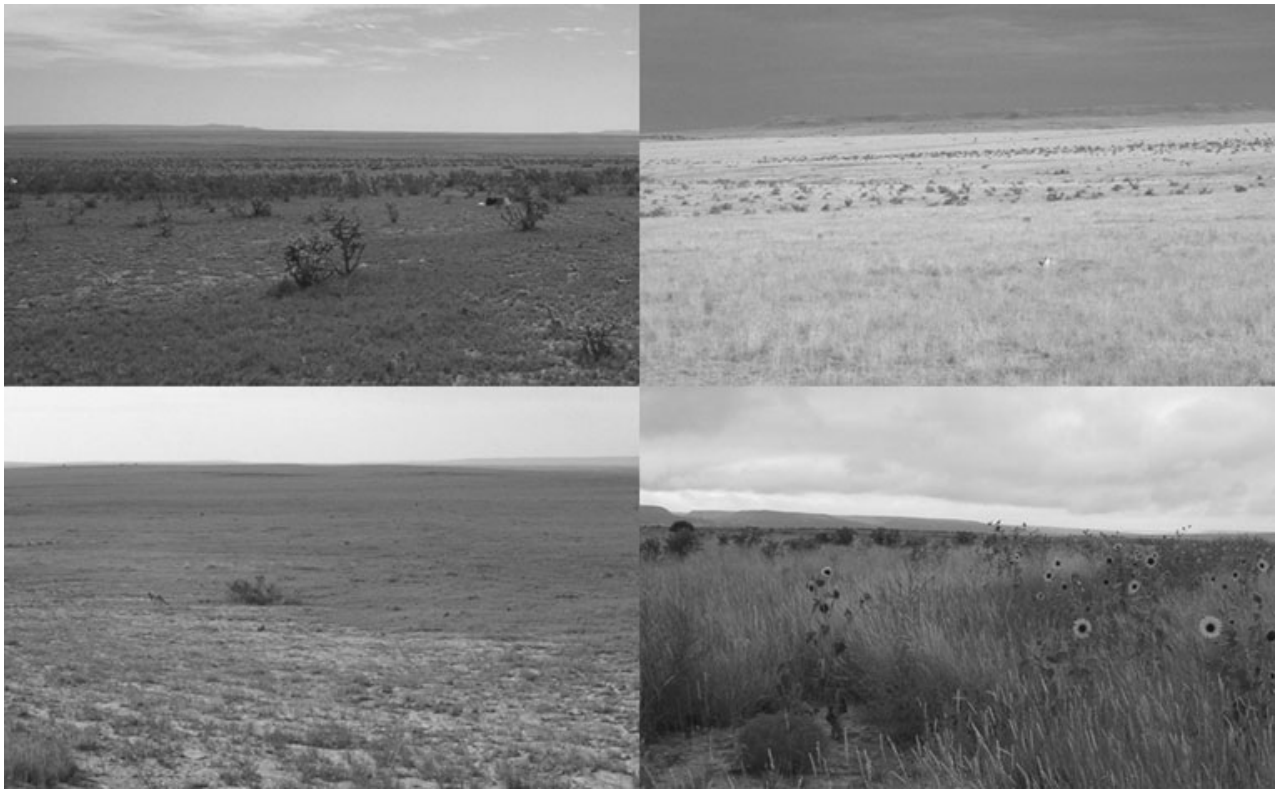


dropped. Community indices were log transformed to improve normality.

\section{Results}

Between 2002 and 2004, 185 small mammal trapping grids were sampled for a total of 740 grid nights; 641 rodents were captured, marked, and released. Two vegetation variables (mean vegetation height and mean point height) were excluded from the analysis due to high correlations with other variables. Two sampling grids, statistical outliers, were excluded due to their high degree of influence. Grid capture rates, defined as the number of captures/number of operable trap nights, ranged from 0 to 0.35 . Four species accounted for $86.8 \%$ of all captured animals: deer mice (Peromyscus maniculatus; $30.0 \%$ ), Ord's kangaroo rat (Dipodomys ordii; $24.7 \%$ ), northern grasshopper mice (Onychomys leucogaster; $21.1 \%$ ), and silky pocket mice (Perognathus flavus; $11.0 \%)$. Other species captured included whitefooted mice (Peromyscus leucopus; $4.9 \%$ ), thirteen-lined ground squirrel (Spermophilus tridecemlineatus; $0.8 \%$ ), spotted ground squirrel (Spermophilus spilosoma; $0.8 \%$ ), western harvest mice (Reithrodontomys megalotis; $2.7 \%$ ), and southern plains wood rat (Neotoma micropus; $3.8 \%$ ).

The two primary canonical axes accounted for over $50 \%$ of the variance in vegetation structure between sampling grids (Table 1). The first axis describes the total amount of vegetation present, from sparse to dense. The second axis describes the amount of vegetative litter (Fig. 3). Additional axes described variations of the same general pattern. However, the two primary axes accounted for only $6 \%$ of the variance in small mammal abundances and additional axes were irrelevant (Table 1).

All four small mammal community indices were significantly negatively related to percent litter and positively related to either shrub density or shrub height (Table 2). While three of the four models were statistically significant,

Table 1 Canonical correlation results for the first four canonical axes describing the relationship between vegetation structure and small mammal capture rates in southeastern Colorado, USA, 2001-2004

\begin{tabular}{lllll}
\hline $\begin{array}{l}\text { Canonical } \\
\text { axis }\end{array}$ & $\begin{array}{l}\text { Canonical } \\
\text { correlation }\end{array}$ & Eigenvalue & $\begin{array}{l}\text { Dependent } \\
\text { variable }^{\mathrm{a}}\end{array}$ & $\begin{array}{l}\text { Explanatory } \\
\text { variable }^{\mathrm{b}}\end{array}$ \\
\hline 1 & 0.438 & 0.238 & 0.041 & 0.330 \\
2 & 0.342 & 0.133 & 0.018 & 0.176 \\
3 & 0.254 & 0.069 & 0.003 & 0.133 \\
4 & 0.193 & 0.039 & 0.004 & 0.106 \\
\hline
\end{tabular}

${ }^{\text {a }}$ Proportion of total variance in small mammal abundance estimates explained by canonical variate

${ }^{\mathrm{b}}$ Proportion of total variance in vegetation structure variables explained by canonical variate the explanatory power was low. No other structural variables entered into the model based on an entry significance requirement of $P=0.15$. Inclusion of season or transect as either explanatory or grouping variables did not alter results.

\section{Discussion}

Despite the weak explanatory power of the analysis, small mammal communities did show a pattern of microhabitat association related to vegetation structure (Fig. 3). Deer mice and southern plains wood rats occurred more often in areas of denser vegetation. Northern grasshopper mice, kangaroo rats, and ground squirrels were more often found in areas with a high percentage of bare ground while pocket mice were found in areas free of vegetative litter. These approximate patterns are similar to those reported in other landscapes; pocket mice are generally found in low numbers across a range of habitats but prefer arid areas with sparse vegetation, Ord's kangaroo rats and ground squirrels prefer sparse litter, and deer mice are generalists (Kaufman et al. 2000; Schorr et al. 2007). In general, the richest and most diverse rodent communities were found in areas of reduced litter cover and some degree of structural heterogeneity. The relationship between rodent community diversity and landscape heterogeneity has been well documented (Kaufman and Kaufman 1989; Clark and Kaufman 1991).

White et al. (2004) linked changes in desert rodent communities to habitat changes through a combination of energetic and behavioral modeling. They found that open grassland communities were generally dominated by relatively scarce, large-bodied rodents such as kangaroo rats or ground squirrels. However, as sites were gradually converted to shrubland, community dominance shifted to more abundant, smaller bodied species such as pocket mice or grasshopper mice. Other studies have reported similar patterns, with larger bodied species such as kangaroo rats being the dominant foragers in open, intershrub space (Brown and Liebermann 1973; Rosenzweig 1973; Schorr et al. 2007) due to their suite of anti-predator adaptations including social behavior (Bartholomew and Caswell 1951; Webster and Webster 1971) and bipedal movement (Longland and Price 1991). Areas of thick vegetation and litter are typically characterized by small, seed-eating mice such as deer mice (Kaufman et al. 2000; Schorr et al. 2007) whose solitary behavior and quadrapedal movement may restrict their habitat use (Longland and Price 1991; White et al. 2004). Reed et al. (2005) reported that rodents foraging for seeds in areas with sparse litter are searching for seeds in a two-dimensional environment, while areas with litter must forage in a three-dimensional environment. In general, our results agreed with these conclusions with one exception; southern plains wood rats, the 


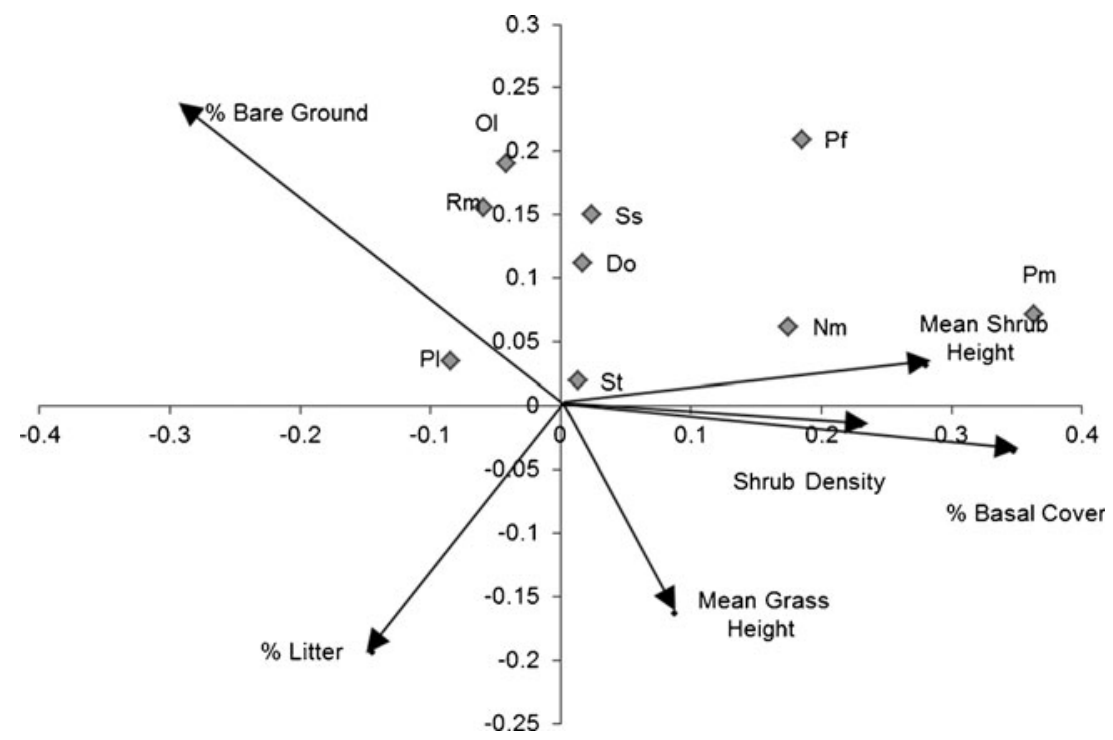

Fig. 3 Ordination diagram showing the distribution of small mammal species (diamonds) in relation to vegetation structure (arrows) in southeastern Colorado, USA, 2001-2004. Small mammal species are: $P m=P$. maniculatus (deer mouse), Do $=D$. ordii (Ord's kangaroo rat), $O l=O$. leucogaster (northern grasshopper mouse), $P f=P$. flavus (silky

largest rodent we captured, were found exclusively in areas of moderate to high shrub density and thereby skewed our biomass indices accordingly.

In our study area, three primary land use practices control the variation in vegetation structure. Livestock grazing, excluded from the PCMS, took place at varying intensity on two of the six study sites or on one third of the sampling grids. Mechanized infantry training took place on another two sites. Fire suppression was actively practiced on four of six sites, though due to the lack of fuel, fires were rare on the remaining two (grazed) sites. With respect to these three disturbances, the two primary vegetation gradients are easily interpreted. The primary gradient, describing the proportion of bare ground to live basal coverage, both shrub and grass, was driven by grazing intensity. The secondary gradient, describing litter accumulation, was driven by mechanized infantry training in concert with fire suppression. Fire suppression, particularly in ungrazed areas, results in the accumulation of grasses and other fine fuels as well as shrubland expansion (Valone and Kelt 1999). The addition of mechanized infantry training to pocket mouse), $S s=S$. spilosoma (spotted ground squirrel), $N m=N$. micropus (Southern Plains wood rat), $P l=P$. leucopus (white-footed mouse), $R m=R$. megalotis (western harvest mouse), $S t=S$. tridecemlineatus (thirteen-lined ground squirrel)

this disturbance regime limits shrubland expansion but enhances litter accumulation (Milchunas et al. 2000).

The link between landscape heterogeneity and wildlife community diversity has been well established for small mammals (Clark and Kaufman 1991; Fleharty and Channell 1997) as well as other animals (Lyon et al. 2000). Historically, this heterogeneity was maintained through the interactions of multiple disturbances of different intensities and frequencies resulting in higher biodiversity and species richness (Valone and Kelt 1999). The replacement of this dynamic interaction with one overwhelming influence, livestock grazing, has resulted in the homogenizing of landscapes and the loss of native southwestern grasslands through desertification and shrubland expansion (Hobbs and Huenneke 1992). In our study area, the addition of mechanized infantry training to the disturbance regime appeared to limit shrubland expansion and enhanced landscape heterogeneity, particularly when coupled with fires to remove accumulated vegetative litter.
Table 2 Results of stepwise regression analysis of the relationship between small mammal community indices and vegetation structure, southeastern Colorado, USA, 2001-2004

\begin{tabular}{lllllll}
\hline Community index & $\begin{array}{c}\text { Primary } \\
\text { variable }\end{array}$ & Partial $R^{2}$ & Secondary variable & Partial $R^{2}$ & Model $R^{2}$ & Model $P$ \\
\hline Diversity & \% Litter & 0.022 & Shrub density & 0.021 & 0.043 & 0.046 \\
Richness & \% Litter & 0.027 & Mean shrub height & 0.025 & 0.052 & 0.029 \\
$\begin{array}{l}\text { Mean per capita } \\
\text { biomass }\end{array}$ & \% Litter & 0.013 & Shrub density & 0.015 & 0.028 & 0.100 \\
Total biomass & \% Litter & 0.024 & Shrub density & 0.023 & 0.046 & 0.040 \\
\hline
\end{tabular}


While species abundance was significantly correlated with vegetation structure, the ability of the model to account for rodent abundance and community composition was low. Similarly, while community richness and diversity were significantly correlated to vegetative litter and structural variation, the explanatory power of the model was low. Reasons for this low explanatory power in our models are varied. Other factors such as floristics, soil characteristics (Harrison and Bardgett 2010), or level of seed predation, while related to vegetation structure or microhabitat, may play a greater role in explaining small mammal community composition (Reed et al. 2005; Schorr et al. 2007). Reed and Slade (2009) found no relationship between environmental variability and vital rates (survival and reproduction) of prairie voles (Microtus ochrogaster). Reed et al. (2005) suggested that rodent foraging in tallgrass prairie was affected by microhabitat with the amount of litter being an important factor in seed predation. VanNimwegen et al. (2008) concluded that burrowing and soil disturbance from prairie dogs (Cynomys spp.) were more important in structuring rodent communities than vegetation cropping. Predation of rodents by native mesocarnivores could also shape rodent survival rates (Schorr et al. 2007) and rodent community diversity (Henke and Bryant 1999), which would not be evident in data collected from trapping grids.

Overall, our results indicated that small mammal communities benefited from a system of interacting disturbances and the resulting landscape mosaic. In turn, it can be assumed that other predatory species such as mesocarnivores or raptors would benefit from this enhanced prey base (Reed et al. 2004; Thompson and Gese 2007; Johnson and Horn 2008). Ecosystems, particularly grasslands, are dynamic entities whose vitality is maintained through the interaction of succession and multiple abiotic disturbances (Sieg 1997; Davidson et al. 2010; Leonard et al. 2010). Managers of grassland landscapes would do well to consider how different disturbances may complement each other (Davidson et al. 2010) and to manage for a diverse disturbance regime (Leonard et al. 2010).

\footnotetext{
Acknowledgments Funding and logistical support were provided by the U.S. Army, Directorate of Environmental Compliance and Management, Fort Carson, Colorado, through the U.S. Fish and Wildlife Service, Colorado Assistance Office, Golden, Colorado, and the Utah Cooperative Fish and Wildlife Research Unit at Utah State University. Additional support was provided by the U.S. Department of Agriculture, Wildlife Services, National Wildlife Research Center at Utah State University, Logan, Utah. We thank T. Warren, B. Rosenlund, G. Belew, R. Bunn, D. Sharps, and M. Klavetter for logistical assistance and E. Joyce, J. White, E. Cleere, M. Watkins, D. Degeranno, A. Larkins, C. Roemer, D. Fletcher, W. Ulrey, S. Schopman, C. Gazal, A. Knipps, J. Garner, and C. Briggs for field assistance. We thank M. Conner, M. Ernest, J. MacMahon, and F. Provenza for review of the manuscript. Research protocols were approved by the Institutional Animal Care and Use Committees at the National Wildlife Research Center and Utah State University.
}

\section{References}

Bartholomew GA, Caswell HH (1951) Locomotion in kangaroo rats and its adaptive significance. J Mammal 32:155-169

Berlow EL, D'Antonio CM, Reynolds SA (2002) Shrub expansion in montane meadows: the interaction of local-scale disturbance and site aridity. Ecol Appl 12:1103-1118

Bock CE, Bock JH (1990) Effects of fire on wildlife in southwestern lowland habitats. In: Krammes JS, DeBano LF, M.J. Zwolinski MJ (eds) Effects of fire in management of southwestern natural resources: workshop proceedings. U.S. Forest Service, General Technical Report RM-191, Rocky Mountain Forest and Range Experiment Station, Fort Collins, Colorado, pp 50-64

Briggs JM, Knapp AK, Brock BL (2002) Expansion of woody plants in tallgrass prairie: a fifteen-year study of fire and fire-grazing interactions. Am Midl Nat 147:287-294

Brown JH, Liebermann GA (1973) Resource utilization and coexistence of seed-eating desert rodents in sand dune habitats. Ecology 54:788-797

Clark BK, Kaufman DW (1991) Effects of plant litter on foraging and nesting behavior of prairie rodents. J Mammal 72:502-512

Dale MR (1999) Spatial pattern analysis in plant ecology. Cambridge University Press, Cambridge

Davidson AD, Ponce E, Lightfoot DC, Fredrickson EL, Brown JH, Cruzado J, Brantley SL, Sierra-Corona R, List R, Toledo D, Ceballos G (2010) Rapid response of a grassland ecosystem to an experimental manipulation of a keystone rodent and domestic livestock. Ecology 91:3189-3200

Fleharty ED, Channell R (1997) Historical implications and characteristics of assemblages of small mammals in west-central Kansas. In: Yates TL, Gannon WL, Wilson DE (eds) Life among the Muses: papers in honor of James S. Findley. The Museum of Southwestern Biology, Special Publication 3, Albuquerque, New Mexico, pp 155-178

Harrison KA, Bardgett RD (2010) Influence of plant species and soil conditions on plant-soil feedback in mixed grassland communities. J Ecology 98:384-395

Henke SE, Bryant FC (1999) Effect of coyote removal on the faunal community in western Texas. J Wildl Manag 63:1066-1081

Hobbs RJ, Huenneke LF (1992) Disturbance, diversity, and invasion: implications for conservation. Conserv Biol 6:324-337

Johnson MD, Horn CM (2008) Effects of rotational grazing on rodents and raptors in a coastal grassland. West North Amer Nat 68:444-452

Jongman RHG, Ter Braak CTF, Van Tongeren OFR (1995) Data analysis in community and landscape ecology. Cambridge University Press, Cambridge

Kaufman DW, Kaufman GA (1989) Burrow distribution of the thirteen-lined ground squirrel in grazed mixed-grass prairie: effect of artificial habitat structure. Prairie Nat 21:81-83

Kaufman DW, Kaufman GA, Clark BK (2000) Small mammals in native and anthropogenic habitats in the Lake Wilson area of north-central Kansas. Southwest Nat 45:45-60

Knight DH (1994) Mountains and plains, the ecology of Wyoming landscapes. Yale University Press, New Haven

Leonard S, Kirkpatrick J, Marsden-Smedly J (2010) Variation in the effects of vertebrate grazing on fire potential between grassland structural types. J Appl Ecol 47:876-883

Longland WS, Price MV (1991) Direct observations of owls and heteromyid rodents: can predation risk explain microhabitat use? Ecology 72:2261-2273

Lyon LJ, Huff MH, Smith JK (2000) Fire effects on fauna at landscape scales. In: Smith JK (ed) Wildland fire in ecosystems: effects of fire on fauna. General Technical Report RMRS-GTR-42-vol.1, USDA Forest Service Rocky Mountain Research Station, Fort Collins, Colorado, pp 43-49 
McGarigal K, Cushman S, Stafford S (2000) Multivariate statistics for wildlife and ecology research. Springer, New York

Milchunas DG, Schulz KA, Shaw RB (1999) Plant community responses to disturbance by mechanized military maneuvers. J Environ Qual 28:1533-1547

Milchunas DG, Schulz KA, Shaw RB (2000) Plant community structure in relation to long-term disturbance by mechanized military maneuvers in a semiarid region. Environ Manag 25:525-539

Morin PJ (1999) Community ecology. Blackwell Science, Malden

Otis DL (1997) Analysis of habitat selection studies with multiple patches within cover types. J Wildl Manag 61:1016-1022

Reed AW, Slade NA (2009) Environmental correlates of survival and reproduction in old-field rodents. J Mammal 90:680-685

Reed AW, Kaufman GA, Rintoul DA, Kaufman DW (2004) Influence of prey abundance on raptors in tallgrass prairie. Prairie Nat 36:23-32

Reed AW, Kaufman GA, Kaufman DW (2005) Rodent seed predation and GUDs: effect of burning and topography. Can J Zool 83:1279-1285

Rosenzweig ML (1973) Habitat selection experiments with a pair of coexisting heteromyid rodent species. Ecology 62:327-335

Schorr RA, Siemers JL, Lukacs PM, Gionfriddo JP, Sovell JR, Rondeau RJ, Wunder MB (2007) Using survival of rodents to assess quality of prairie habitats. Southwest Nat 52:552-563

Shaw RB, Diersing VE (1990) Tracked vehicle impacts on vegetation at the Piñon Canyon Maneuver Site, Colorado. J Environ Qual 19:234-243

Shaw RB, Anderson SL, Schulz KA, Diersing VE (1989) Plant communities, ecological checklist, and species list for the U.S. Army
Pinon Canyon Maneuver Site, Colorado. Colorado State University Science Series 37, Fort Collins, Colorado

Sieg CH (1997) The role of fire in managing for biological diversity on native rangelands of the northern Great Plains. In: Conserving biodiversity on native rangelands: symposium proceedings. U.S. Forest Service General Technical Report RM-GTR-298, Rocky Mountain Range and Experiment Station, Fort Collins, Colorado, pp 31-38

Ter Braak CJF (1986) Canonical correspondence analysis: a new eigenvector technique for multivariate direct gradient analysis. Ecology 67:1167-1179

Thompson CM, Gese EM (2007) Food webs and intraguild predation: community interactions of a native mesocarnivore. Ecology 88:334-346

Turner MG, Gardner RH, O’Neill RV (2001) Landscape ecology in theory and practice. Springer, New York

Valone TJ, Kelt DA (1999) Fire and grazing in a shrub-invaded grassland community; independent or interactive ecological effects? J Arid Environ 42:15-28

VanNimwegen RE, Kretzer J, Cully JF Jr (2008) Ecosystem engineering by a colonial mammal: how prairie dogs structure rodent communities. Ecology 89:3298-3305

Webster DB, Webster M (1971) Adaptive value of hearing and vision in kangaroo rat predator avoidance. Brain Behav Evol 4:310-322

White EP, Ernest SKM, Thibault KM (2004) Trade-offs in community properties through time in a desert rodent community. Am Nat 164:670-676

Wiens JA (1989) Spatial scaling in ecology. Functional Ecol 3:385397 